\title{
PENCATATAN TRANSAKSI AKUNTANSI BESERTA FUNGSI MANAJEMEN UNTUK MENUNJANG PENGELOLAAN KELONG DI DESA MALANG RAPAT, KECAMATAN GUNUNG KIJANG, KEPULAUAN RIAU
}

\section{Recording Accounting Transaction Along with Mangement Function to Enhance Kelong Governance in Malang Rapat Village, Kecamatan Gunung Kijang, Kepulauan Riau}

\author{
Inge Lengga Sari Munthe ${ }^{1 *}$, Myrna Sofia ${ }^{2}$ \\ ${ }^{1}$ Jurusan Akuntansi, Fakultas Ekonomi, Universitas Maritim Raja Ali Haji, Tanjungpinang \\ ${ }^{2}$ Jurusan Manajemen, Fakultas Ekonomi, Universitas Maritim Raja Ali Haji, Tanjungpinang \\ *Korespondensi : ingemunthe74@gmail.com
}

\begin{abstract}
ABSTRAK
Desa Malang Rapat adalah salah satu desa di kecamatan Gunung Kijang, kabupaten Bintan. Penghasilan utama di desa ini adalah nelayan. Bagi nelayan yang mampu, bisa memiliki kelong. Kelong merupakan alat tangkap tradisional, alat tangkap kelong terbuat dari kayu yang dipasang jaring dibagian tengah laut.Pengabdian masyarakat di desa Malang Rapat bertujuan untuk memberikan penyuluhan mengenaipencatatan transaksi ke buku yang tepat. Pencatatan ini juga disertai bagaimana pelaksanaan fungsi manajemen dengan baik. Selain itu juga masyarakat ingin mengetahui bagaimana membuat proposal yang baik agar dapat memperoleh bantuan. Metode pengabdian dimulai dengan pengamatan untuk mengetahui apa yang diperlukan masyarakat. Setelah itu dilakukan penyuluhan untuk memberikan topiknya. Hasil dari pengabdian ini bahwa masyarakat memerlukan dana untuk dapat memperluas usaha kelongnya. Untuk itu pencatatan akuntansi yang baik sangat diperlukan. Agar dapat memperoleh dana, diajarkan bagaimana cara membuat proposal. Kesimpulannya adalah masyarakat kelong perlu lebih diberi pemahaman dalam pencatatan transaksi akuntansi. Selain itu perlu di bentuk koperasi simpan pinjam di Desa Malang Rapat.
\end{abstract}

Kata Kunci : Akuntansi, Kelong, Dana, Proposal.

\begin{abstract}
Desa Malang Rapat is one of the villages in kecamatan Gunung Kijang, kabupaten Bintan.The main job in this village is fisherman. For capable fisherman, they can own kelong. Kelong is a traditional catcher which is made from wood that has web in the middle of it. Kelong is on the sea. This activity aims to give knowledge about how to record transaction in the right book. It is also combined with how to run business with a proper management function. People in this village wants to know how to make good proposal in order to get fund. It began with observing to know what they needed. After that we taught them along with the topics. The result are villagers needed fund to expand their kelong business. That's why they need a good accounting record. In order to get fund, they are taught how to make a good proposal. In conclusion, that fisherman along with the villagers have to get deepest knowledge in recording accounting transaction. Beside that in Desa Malang Rapat should form koperasi simpan pinjam.
\end{abstract}

Keyword : Acconting, Fund, Kelong, Proposal. 


\section{PENDAHULUAN}

Kabupaten Bintan memiliki rentang wilayah pantai yang panjang sekitar 966,54 km garis pantai. Wilayah laut seluas $86.398,33 \mathrm{~km} 2$ yang mana setara dengan $98,51 \%$ dari total wilayah Kabupaten Bintan. Untuk itu banyak pendapatan yang bisa didapat dari luasnya lautan, agar dapat meningkatkan ekonomi masyarakat Bintan. Beberapa sumber daya yang bisa didapat dari laut ini seperti perikanan, terumbu karang, rumput laut dan hutan mangrove. Umumnya profesi nelayan. Nelayan mendapat ikannya dengan menggunakan kelong.

Kelong merupakan alat tangkap tradisional, alat tangkap kelong terbuat dari kayu yang dipasang jaring dibagian tengah laut. Kelong ditopang oleh beberapa drum plastik agar dapat mengapung diatas permukaan laut, kelong bisaanya diletakan pada dasar laut sedalam enam meter dengan pondasi kayu sepanjang 20 meter (Abdulkadir, 2010).

Selain itu kelong ini dapat terhubung dengan daratan dengan dihubungkan dengan kayu, seperti pelantar. Ada kelong yang bisa berpindah tempat yang dapat terapung bebas di luar pantai. Beberapa kelong ada yang merupakan bangunan besar yang terbentuk dari beberapa grup kelong, hingga menjadi komunitas lepas pantai yang besar.

Nelayan bisaanya menangkap ikan adalah ketika malam hari. Sekitar jam 6 sore, mereka pergi ke tengah laut dan menunggu ikan. Kemudian pulang di waktu subuh. Sehingga pada pagi dan siang hari merupakan waktu istirahat nelayan. Dalam menangkap ikan juga ada hari-hari tertentu. Tidak bisa setiap hari untuk menangkap ikan. Pada saat "bulan gelap", barulah nelayan pergi ke laut untuk memancing. Bila "bulan terang", nelayan tidak pergi ke laut. Hal ini juga tergantung cuaca. Bila cuaca tidak baik, maka nelayan juga tidak pergi ke laut.

Pemilik kelong juga merupakan nelayan. Dalam hal pencatatan penerimaan uang atau pengeluaran uang, umumnya mereka mencatat di buku sederhana. Ada juga yang tidak mencatat sama sekali. Bila pencatatan penerimaan dan pengeluaran dicatat dengan baik, maka akan bisa mengetahui berapa pendapatan dan pengeluaran yang sesungguhnya. Apalagi nelayan juga tidak setiap hari bisa ke laut. Dengan pencatatan transaksi yang baik, maka dapat diketahui biaya-biaya yang besar saat penangkapan laut. Pada saat penerimaan juga bisa dapat menabung. Sehingga saat nelayan tidak pergi ke laut, maka dapat menutupi biaya sehari-hari. Umumnya pencatatan transaksi keuangannya masih sederhana. Hanya sebatas catatan di buku, tanpa memisahkan yang mana penerimaan dan pengeluran. Hal ini disebabkan karena penyimpanan data-data belum tertata rapi. Mungkin hanya mencatat berapa jumlah hasil tangkapan yang diterima dari nelayan. Selain dari itu, diperlukan juga perencanaan dari kegiatan di kelong. Beserta pengendalian dari aktivitas di kelong juga. Tapi tidak terdokumentasi dengan baik.

Pemilik kelong juga berharap akan bisa mendapat bantuan untuk kelangsungan usahanya. Mereka berharap dana tersebut untuk membuat kelong baru. Kelong umur ekonomisnya hanya 4 atau 5 tahun saja. Selama ini, mereka susah mendapatkan bantuan. Umumnya mereka pinjam ke bank, dengan jaminan tanah mereka. Untuk itu perlu dibuat proposal untuk minta bantuan dana yang baik.

Bila pencatatan transaksi keuangan dilakukan dengan tepat, maka pemilik kelong akan mengetahui hasil tangkapan apa yang paling banyak. Atau dapat mengetahui nelayan mana yang paling banyak atau sedikit hasil tangkapannya. Dengan pencatatan yang baik juga, maka akan mengetahui kuantitas dan harga satuan yang tepat. Hal ini dapat membantu pembuatan anggaran dalam proposal bantuan mereka. 
Sehingga dari penjelasan diatas, tujuan diadakan pengabdian masyarakat ini adalah sebagai berikut :

1. Membuat buku-buku transaksi yang sesuai dengan kondisi di lokasi kelong.

2. Membuat buku pembantu berdasarkan nelayan yang memberi hasil tangkapan.

3. Mengadakan penyuluhan mengenai 5 fungsi manajemen yaitu : perencanaan, pengorganisasian, pengaraan, pemotivasian dan pengawasan / pengendalian.

4. Memberikan penyuluhan mengenai pembuatan proposal permintaan bantuan untuk keberlangsungan kelong.

\section{METODE}

\section{Waktu dan Tempat}

Pengabdian kepada masyarakat ini dilaksanakan pada bulan Agusus 2018 di Desa Malang Rapat, Kecamatan Gunung Kijang, Kabupaten Bintan.

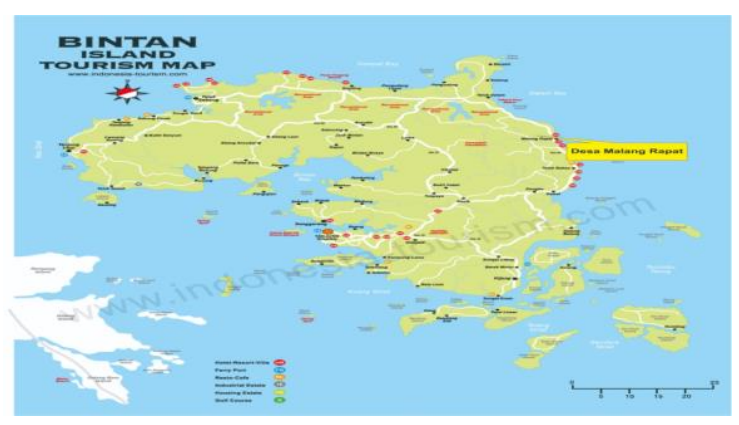

Gambar 1 Lokasi Desa Malang Rapat

\section{Metode Pelaksanaan}

Metode pelaksanaan pengabdian dimulai dari pengamatan. Pengamatan ini berupa mengajukan pertanyaan ke beberapa pemilik kelong. Dari pengamatan ini, dapat diketahui sebagai berikut :

1. Aktivitas nelayan mulai dari kapan hari yang baik untuk menangkap hasil laut, menangkap hasil laut, peralatan yang dibutuhkan sampai penjualan hasil laut.

2. Pencatatan transaksi keuangan.

3. Keinginan para nelayan untuk memperluas usahanya.

Setelah pengamatan, barulah kami mengadakan penyuluhan sesuai topik pengabdian. Disini kami juga menambahkan topik mengenai pembuatan proposal bantuan dana. Dari penyuluhan, para peserta juga menanyakan hal-hal mengenai topik. Kemudian dilakukan juga evaluasi mengenai hasil penyuluhan ini.

\section{HASIL DAN PEMBAHASAN}

\section{Analisis Situasi}

Desa Malang Rapat secara administrasi terletak di wilayah Kecamatan Gunung Kijang. Berikut batas-batasnya.

* Sebelah utara : berbatasan dengan Desa Berakit

* Sebelah selatan : berbatasan dengan Desa Teluk Bakau

* Sebelah barat : berbatasan dengan Desa Toapaya Utara

* Sebelah timur : berbatasam dengan Laut Cina Selatan

Luas wilayah Desa Malang Rapat yaitu 771.225 Ha. Terdiri dari 8 RT dan 3 RW. Jarak Desa Malang Rapat ke ibu kota Kecamatan yaitu $15 \mathrm{KM}$. Jarak desa ke ibu kota Kabupaten yaitu 12 KM. Sedangkan jarak ke ibu kota Provinsi yaitu 60 KM.Kondisi tanah Desa Malang Rapat umumnya berpasir. Luas lahan yang ada terbagi dalam beberapa peruntukan seperti untuk fasilitas umum, pemukiman, pertanian, kegiatan ekonomi, hutan dan pantai. Wilayah Desa Malang Rapat dilihat dari topografi ketinggian wilayah Malang Rapat berada pada $0-20 \mathrm{~m}$ dari permukaan air laut dengan keadaan curah hujan rata-rata $20 \mathrm{~mm} / \mathrm{tahun}$, serta suhu rata-rata per tahun adalah $30^{\circ} \mathrm{C}$.

Dalam urutan tenaga kerja untuk nelayan ini, terdapat tiga posisi, yaitu :

1. Toke. Toke adalah pemilik kelong. Toke bisa memiliki lebih dari satu kelong. 
2. Tekong. Tekong adalah pengawas kelong.

3. Anak buah kapal (ABK). ABK ini adalah bawahan dari tekong.

Toke bisa merupakan seorang nelayan. Terkadang toke juga turun untuk pergi ke laut, terkadang tidak. Sementara tekong dan ABK pasti pergi untuk turun ke laut memancing. Satu orang tekong mengawasi satu kelong.

Tekong dan ABK pergi ke laut untuk memancing. Bila dapat hasil pancingan, diberikan ke Toke. Kemudian Toke menjual ke pedagang yang khusus untuk membeli hasil laut. Setelah terjual, toke mendapatkan uang hasil penjualan. Kemudian umumnya terjadi bagi hasil antara Toke, Tekong dan ABK. Ada juga sistem penggajian secara tetap atau bulanan. Bagi hasil adalah merupakan total penjualan dikurangi dengan beban operasional. Untuk itu, toke ada yang memberikan nota-nota bisa merupakan hasil penjualan atau pembayaran ke tekong dan ABK. Tujuannya agar ada transparasi diantara mereka. Sehingga toke si pemilik kelong malah tidak memiliki nota-nota itu.

Saat tiba di lokasi kelong, nelayan langsung melepaskan lilitan tali waring dan menurunkan waring ke dalam air secara perlahan-lahan dengan menggunakan roller dengan kedalaman \pm 4,5 meter. Setelah itu, berikutnya menurunkan pemberat utama yang di ikatkan ditengah-tengah pelantar. Gunanya adalah mempertahankan posisi waring pada saat didalam air. Kemudian mempersiapkan peralatan lampu, lampu yang digunakan 3 buah setiap lampu yang digunakan memiliki besar daya 35 watt. Lampu-lampu yang di gunakan digantung ditengah-tengah pelantar dengan posisi \pm 1 meter di atas permukaan perairan. Untuk menghidupkan lampu, nelayan menggunakan genset dengan kapasaitas daya 230 v. Setelah semuanya siap, nelayan menunggu hingga hari mulai gelap untuk menyalakan lampu. Gunanya lampu dinyalakan agar dapat melihat ikan berkumpul dibawah pelantar atau diatas waring. Lampu dinyalakan sekitar 3-4 jam. Setelah ikan banyak berkumpul barulah dilakukan proses penarikan waring dengan menggunakan roller. Roller diputar oleh dua orang. Saat proses penarikan waring, pemberat diangkat secara perlahan-lahan. Lampu juga satu persatu diangkat dan dimatikan hingga tersisa satu lampu saja yang dibiarkan hidup. Gunanya bertujuan agar ikan terkonsentrasi dalam satu titik cahaya lampu. Pada saat waring akan mencapai permukaan air, maka waring semakin cepat ditarik. Hal ini dilakukan agar ikanikan yang berada diatas waring tidak dapat melarikan diri. Setelah semua waring berada diatas permukaan, hasil laut yang tertangkap diambil dengan menggunakan secoop net/tanggu. Kemudian hasil laut itu, dimasak dengan kompor diatas kelong saat itu juga. Setelah masak, barulah mereka pulang.

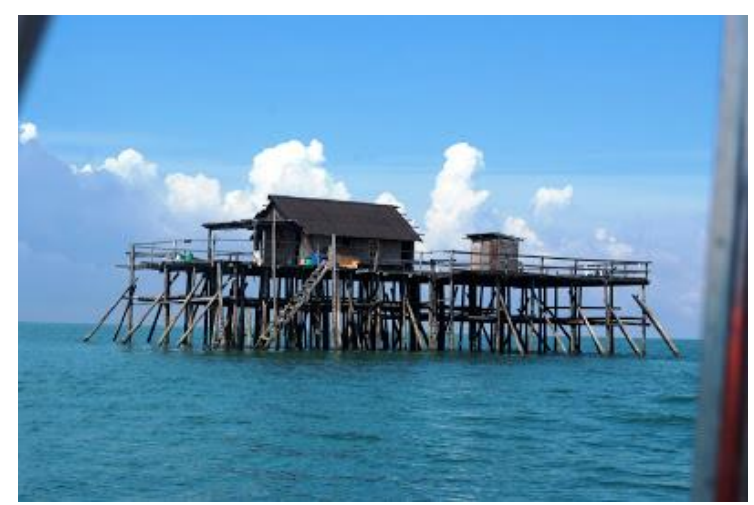

Gambar 2 Kelong

Hasil laut yang banyak mereka tangkap adalah ikan bilis. Setelah mereka pulang, hasil laut ini dipilah dulu. Tujuannya untuk menjadikan itu satu kelompok saja. Misalnya : dapat ikan bilis, tapi bisa jadi ada ikan lain. Sehingga dikelompokkan berdasarkan jenis. Kemudian, hasil laut ini dijemur di terik matahari.

Biaya-biaya yang dikeluarkan untuk kelong ini bisa dikelompokkan menjadi dua jenis yaitu : biaya variabel dan biaya tetap. Biaya variabel terjadi bila ada penangkapan ikan di laut. Sementara biaya tetap terjadi, ada atau tidak adanya penangkapan ikan di laut. Biaya tetapnya 
adalah sebagai berikut : biaya makan dan gaji ABK. Biaya variabelnya adalah sebagai berikut :

1. Solar baik untuk kelong maupun boat.

2. Garam dan es.

3. Pemeliharaan mesin.

4. Ongkos pilih bilis.

Para nelayan ini ingin mendapatkan ikan yang banyak juga. Mereka juga ingin kehidupan yang lebih baik. Toke ingin menambah kelong. Tekong dan ABK juga ingin punya kelong sendiri. Tapi mereka terbatas dalam hal pendanaan. Untuk itu mereka memerlukan bantuan dana. Ada 3 barang yang penting untuk dibeli, yaitu :

1. Kayu. Kayu ini untuk membuat kelong. Kayu yang digunakan adalah kayu yang berkualitas, dimana harganya mahal. Dengan kayu yang baik, maka umur ekonomis kelong juga bisa lama.

2. Drum plastik. Drum digunakan untuk membuat kelong mengapung. Untuk 1 kelong, diperlukan banyak drum plastik.

3. Kompor. Kompor digunakan untuk memasak di atas kelong, setelah mendapatkan hasil laut.

Dari hasil pengamatan diatas, maka dapat disimpulkan bahwa umumnya transaksi masih dicatat seadanya atau bahkan tidak dicatat. Selain itu pemilik kelong juga kesulitan untuk mendapatkan bantuan dana.

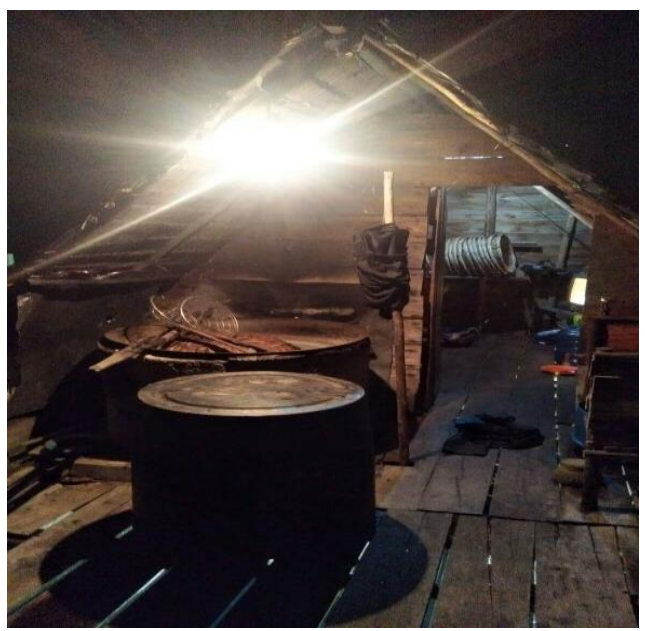

Gambar 3 Isi di dalam kelong

\section{Penyuluhan}

Selama pengamatan, kami sebagai tim pengabdian selalu memberikan saran agar sebaiknya semua penerimaan dan pengeluaran itu dicatat. Berhubung mereka juga ingin mendapatkan bantuan, maka salah satu topik juga adalah bagaimana membuat proposal yang baik. Hal ini agar dapat menarik perhatian calon donor.

Pada tanggal 25 Agustus 2018, kami mengadakan penyuluhan dengan pemilik kelong. Berikut topik-topik yang diberikan.

\section{A. Jurnal khusus}

Dalam akuntansi, terdapat empat buku jurnal khusus (Soemarso,2002) yaitu :

a. Buku penjualan

b. Buku pembelian

c. Buku penerimaan kas

d. Buku pengeluaran kas

Akan lebih baik bila masing-masing mempunyai 1 buku khusus

\section{Buku penjualan}

Buku penjualan adalah buku yang berisi transaksi penjualan secara kredit saja. Di dalam buku ini berisi kolom berupa tanggal, nama pelanggan dan jumlah. Bila pelanggannya banyak, maka akan dibentuk buku pembantu per pelanggan. Hal ini dibuat untuk mengetahui pelanggan mana yang taat dalam membayar piutangnya dan pelanggan potensial yang sering membeli dari kelong. Penjualan kredit menimbulkan piutang dagang.

\section{Buku pembelian}

Buku pembelian adalah buku yang berisi transaksi pembelian secara kredit saja. Dalam buku ini berisi kolom berupa tanggal, nama pemasok dan jumlah. Bila pemasoknya banyak, maka akan dibentuk buku pembantu per pemasok. Gunanya agar dapat mengetahui berapa banyak yang bisa diberikan oleh pemasok sehingga mengetahui pemasok yang sering dapat banyak hasil tangkapan. 


\section{Buku penerimaan kas}

Buku penerimaan kas adalah buku yang berisi transaksi penerimaan kas secara tunai. Umumnya dari hasil penjualan atau pendapatan. Misal hasil tangkapan dari si nelayan tadi, dijual ke pihak luar secara tunai. Selain itu, buku ini juga mempunyai hubungan dengan buku penjualan. Bila piutang dilunasi, maka dicatat di buku penerimaan kas.

\section{Buku pengeluaran kas}

Buku pengeluaran kas adalah buku yang berisi transaksi pengeluaran kas secara tunai. Umumnya bila kita membayar si nelayan tadi dengan tunai. Atau pembelian apapun secara tunai. Buku ini juga mempunyai hubungan dengan buku pembelian. Bila hutang dilunasi, maka dicatat di buku pengeluaran kas.

Buku harian (jurnal) khusus mempunyai keuntungan sebagai berikut :

1. Dalam buku ini dapat disediakan kolom-kolom khusus untuk beberapa jenis tertentu. Dengan cara ini penulisan nama akun pada waktu membuat ayat jurnal tidak perlu dilakukan untuk tiap-tiap transaksi.

2. Setiap buku harian khusus dapat digunakan ntuk mencatat satu jenis transaksi saja, sehingga memungkinkan pembagian tugas pencatatan kepada beberapa orang.

\section{B. Pengarsipan}

Arsip adalah proses pengaturan dan penyimpanan rekaman asli (original record), atau salinannya, sehingga rekaman tersebut dapat ditemukan dengan mudah sewaktu diperlukan. Odgerds (2005) dalam padilah.padil.blogspot.com mendifisikan management arsip sebagai proses pengawasan, penyimpanan dan pengamanan dokumen serta arsip, baik dalam bentuk kertas maupun media elektronik. Untuk itu, pemilik kelong juga harus bisa menyimpan file dengan efisien dan baik. Disini akan diterapkan selaras dengan buku pembantu pelanggan dan pemasok.
Cara pengarsipan bisadengan angka, huruf atau gabungan kedua-duanya. Berikut beberapa langkahpengarsipan.

- Diurutkan berdasarkan tanggal.

- Diurutkan berdasarkan nomor yang paling terkecil.

- Atau berdasarkan alphabet.

Untuk itu nanti akan dipraktekan pada buku jurnal yang dihubungkan dengan buku pembantu sebagai penunjang.

\section{Fungsi-fungsi manajemen}

Fungsi-fungsi manajemen (Team Dosen Manajemen UMRAH, 2016) ada 5 yaitu:

a. Perencanaan. Yaitu proses dan rangkaian kegiatan untuk menetapkan tujuan terlebih dahulu pada suatu jangka waktu atau periode tertentu serta tahapan yang harus ditempuh untuk mencapai tujuan tersebut.

b. Pengorganisasian. Yaitu proses dan rangkaian kegiatan dalam pembagian kerja yang direncanakan untuk diselesaikan oleh anggota kelompok pekerjaan, penentu hubungan pekerjaan yang baik diantara mereka serta pemberian lingkungan dan fasilitas pekerjaan yang kondusif.

c. Pengarahan. Yaitu suatu rangkaian kegiatan untuk memberikan petunjuk atau instruksi dari seorang atasan kepada bawahan atau kepada orang yang diorganisasikan dalam kelompok formal dan untuk pencapaian tujuan bersama.

d. Pemotivasian. Yaitu suatu proses dan rangkaian kegiatan yang dilakukan oleh seorang atasan dalam memberikan inspirasi, semangat dan kegairahan kerja serta dorongan kepada bawahan untuk dapat melakukan suatu kegiatan yang semestinya.

e. Pengendalian. Yaitu suatu proses dan rangkaian kegiatan untuk mengusahakan agar suatu pekerjaan dapat dilaksanakan sesuai dengan rencana yang telah ditetapkan dan tahapan yang harus dilalui. 


\section{Pembuatan proposal}

Dalam berusaha, hal-hal yang diperlukan adalah :kemauan, tenaga, pemikiran dan dana. Tapi terkadang, dalam berusaha terjadi kekurangan dana. Untuk memperoleh dana, bisa dengan cara meminjam uang, atau meminta bantuan ke pihak lain. Untuk itu harus bisa membuat proposal dengan isi yang menarik, agar pihak yang dituju mau memberikan dana.

Isi proposal yang baik, mencakup seperti hal-hal dibawah ini :

1.Judul Proposal

Judul yang menarik adalah judul yang tidak terlalu panjang, tapi sudah mencakup semua keinginan atau kebutuhan yang ingin diperlukan.

2.Latar Belakang

Latar belakang proposal kegiatan ini isinya adalah dasar dan alasan kegiatan itu perlu dilakukan. Misalnya :harus dibuat apa yang menjadi sebab, sehingga memerlukan bantuan dana.

3.Tujuan

Tujuan kegiatan adalah manfaat atau hasil yang diharapkan dari diadakannya kegiatan tersebut. Tujuan permintaan harus dibuat, yang menjadi sasaran akhir.

\section{Kegiatan}

Kegiatan ini menjelaskan tentang kegiatan pokok yang akan dilaksanakan dan dilampirkan dengan jadwal kegiatan secara lengkap pada proposal yang dibuat. Disini harus diterangkan bahwa bila sudah mendapatkan dana, bagaimana memanfaatkan dana tersebut agar dapat sesuai dengan tujuan.

5.Anggaran

Anggaran yang ditulis pada proposal kegiatan ini harus dilampirkan secara terperinci dan sedetail mungkin dan estimasi dana sebaiknya dibuat sedikit

Hubungan Buku Penjualan, Buku Penerimaan kas dan buku pembantu

BUKU PENJUALAN ( JL)

BUKU PEMBANTU SARIP

no bukti mulai dari angka 1 sampai 100

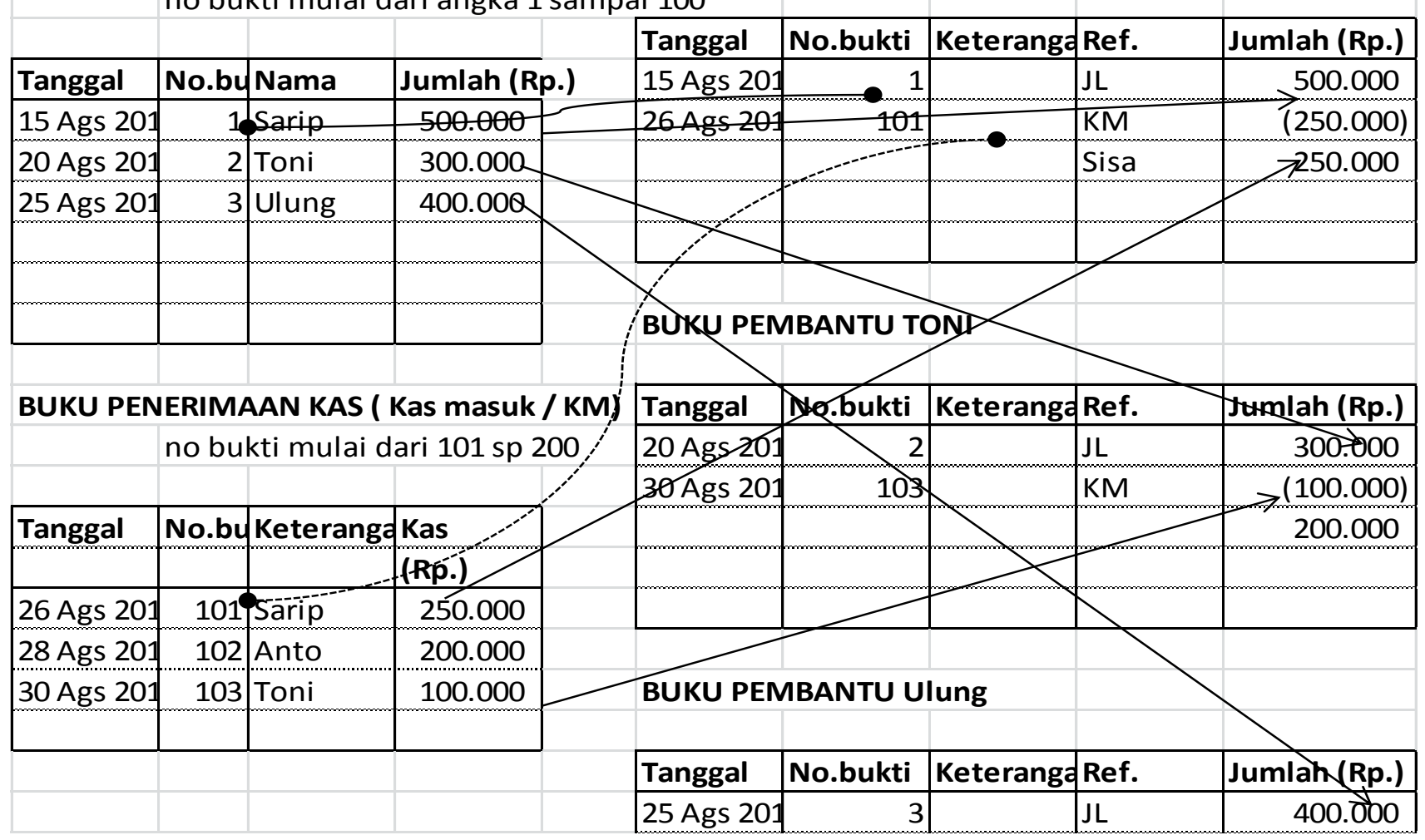

Gambar 4 Skema hubungan buku penjualan, buku penerimaan kas dan buku pembantu 
melebihi dari keadaan sebenarnya yang tujuannya untuk menutupi anggaran dana yang diluar perkiraan dan berikut ini adalah contoh penulisan dari proposal kegiatan. Dalam anggaran, harus dibuat dana itu untuk apa. Dalam proposal, harus juga tahu mengenai jumlah yang dibutuhkan, harga persatuan dan total harga.

Implementasi dari buku pembantu khusus, pengarsipan dan fungsi manajemen adalah dituangkan dalam hubungan seperti Gambar 1. Berikut penjelasannya.

- Setiap transaksi terjadi selalu dicatat di buku yang tepat dengan buktinya. Bila terjadi penjualan kredit, catat di buku penjualan. Bila terjadi di penjualan tunai atau penerimaan uang tunai, catat di buku penerimaan kas. Begitu juga nama pelanggannya.

- Untuk no bukti, dapat dibuka kwitansi dengan no bukti yang berurutan. Begitu juga tanggal sehingga berurutan.

- Masing-masing pelanggan yang terdapat di buku penjualan, dibuatkan buku pembantu masingmasing. Sehingga jika pelanggan tersebut membayar, maka dapat mengurangi piutangnya. Hal ini bertujuan untuk mengetahui saldo dari masing-masing pelanggan.

- Ref. menunjukkan darimana asal transaksi berasal.

- Dari buku pembantu, maka dapat mengetahui siapa pelanggan yang bayarnya cepat, siapa yang lama. Sehingga dapat mengatisipasi penjualan kredit ke pelanggan yang mungkin membayarnya lama.

- Dari buku penerimaan kas, dapat diketahui berapa penerimaan kas selama satu bulan.

BUKU PEMBELIAN ( BL )

BUKU PEMBANTU COKI

no bukti mulai dari angka 201 sampai 300

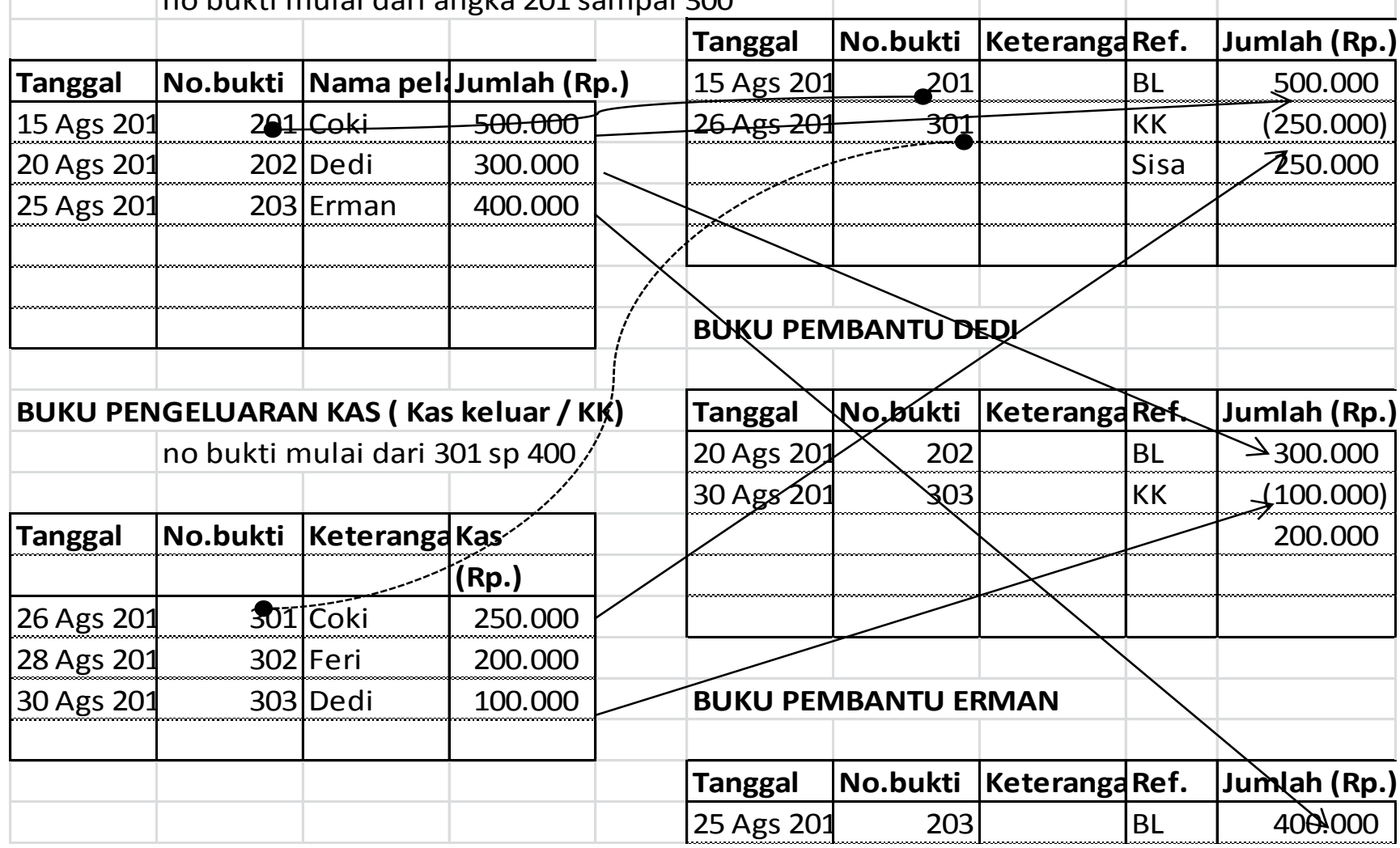

Gambar 5 Hubungan antara buku pembelian, buku pembantu dan buku pengeluaran kas 
- Setiap bulan dapat dihitung saldo piutang dengan cara menghitung total penjualan kredit dikurang dengan total penerimaan kas. Atau juga dapat menghitung total dari saldo masing-masing pelanggan.

- Untuk bukti kwitansi penerimaan harus disimpan atau diarsip dengan baik dan berurutan. Bila ingin memberikan ke ABK, dapat memberi hanya fotocopnya saja.

\section{Hubungan antara buku pembelian, buku pembantu dan buku pengeluaran kas}

Penjelasan untuk hubungan dari Gambar 2 adalah sebagai berikut :

- Setiap transaksi terjadi selalu dicatat di buku yang tepat dengan buktinya. Bukti disini adalah nota pembelian. Bila terjadi pembelian kredit, catat di buku pembelian. Bila terjadi pembelian tunai atau pembayaran uang tunai, catat di buku penerimaan kas. Transaksi pembayaran tunai itu seperti : bayar gaji, pembelian bahan-bahan untuk operasional kelong atau yang lainnya. Begitu juga nama pemasoknya.

- Untuk no bukti,berdasarkan nota pembelian yang diterima. Begitu juga tanggal sehingga berurutan.

- Masing-masing pemasok yang terdapat di buku pembelian, dibuatkan buku pembantu masingmasing. Sehingga jika pemilik kelong membayar pemasok, maka dapat mengurangi hutangnya. Hal ini bertujuan untuk mengetahui saldo dari masing-masing pemasok.

- Ref. menunjukkan darimana asal transaksi berasal.

- Dari buku pembantu, maka dapat mengetahui siapa pemasok yang mungkin harganya wajar, siapa yang tidak. Sehingga dapat mengatisipasi pembelian kredit ke pemasok.
- Dari buku pembayaran kas, dapat diketahui berapa pembayaran kas selama satu bulan.

- Setiap bulan dapat dihitung saldo hutang dengan cara menghitung total pembelian kredit dikurang dengan total pembayaran kas. Atau juga dapat menghitung total dari saldo masing-masing pemasok.

$>$ Setiap akhir bulan dihitung berapa total penerimaan kas dan total pengeluaran kas. Sehingga bila total penerimaan kas dikurang dengan total pengeluaran kas, maka hasilnya adalah berapa kas yang dihasilkan selama 1 bulan.

$>$ Dengan buku-buku ini, pemilik kelong dapat membuat anggaran dan dapat membuat perencanaan untuk menabung. Bisa juga merencanakan untuk membeli kelong yang baru.

Saat diadakan penyuluhan, warga mengajukan pertanyaan. Berikut beberapa pertanyaannya.

1. Apa kegunaan dari buku-buku ini ?

2. Apakah dengan adanya bukubuku ini, bisa mendapatkan kredit dari bank?

3. Bagaimana caranya membuat proposal yang baik?

Berikut jawabannya.

1. Kegunaan buku-buku ini adalah dapat mengetahui dengan pasti berapa jumlah kas masuk, kas keluar, piutang dagang dan utang dagang. Dengan buku ini pemilik kelong dapat membuat anggaran untuk kehidupan yang lebih baik, berapa yang bisa ditabung dan dapat menambah kelong baru.

2. Bila pemilik kelong ini membuat suatu badan usaha, bisa mendapatkan kredit dari bank. Pemerintah juga mulai menetapkan pajak untuk badan usaha kecil menengah. Untuk 
itu diperlukan catatan-catatan akuntansi yang bisa berkembang menjadi laporan keuangan.

3. Kami telah memberikan contoh proposal yang baik. Sebaiknya ada kop surat dari desa atau kelompok usaha. Kemudian juga harus didukung oleh kepala desa setempat.

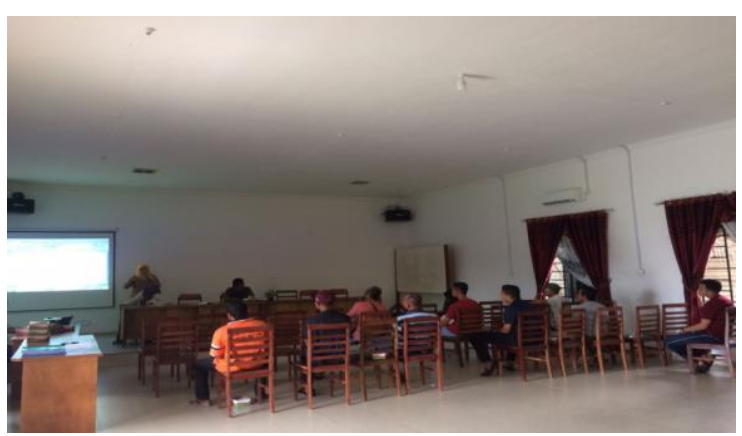

Gambar 6 Penyuluhan

\section{Evaluasi}

Pada saat kunjungan untuk evaluasi, ternyata sudah ada beberapa pemilik kelong yang sudah mulai menerapkan pencatatan akuntansi ini. Bagi yang sudah menerapkan sudah merasakan manfaatnya. Manfaatnya antara lain bahwa, lebih mengetahui berapa uang masuk dan berapa uang keluar. Bila ada masanya mereka tidak pergi ke laut, masih ada sisa uang sehingga dapat memenuhi kebutuhan hidup. Selain itu, mereka juga dapat mulai menyisihkan uang untuk menabung.

Tapi ada juga yang belum menerapkan pencatatan ini. Alasannya adalah karena hal ini merepotkan. Mereka juga tidak sempat untuk mencatatnya. Untuk itu kami arahkan agar para istri dapat membantu pencatatan dari hasil usaha suaminya.

Pemilik kelong juga sebenarnya membutuhkan bantuan dana untuk meningkatkan hasil pendapatannya. Untuk itu mereka berencana menambah jumlah kelong. Salah satu bahan utama untuk membuat kelong adalah kayu. Menurut mereka, kayu yang berkualitas dan cocok untuk pembuatan kelong adalah kayu dari Kabupaten Lingga. Tapi hal ini terbatas, karena takut adanya pembalakan hutan untuk mendapat kayu.

Bila meminjam uang ke bank, bagi mereka agak merepotkan. Karena salah satu syarat adalah ada jaminan. Untuk itu perlu juga dibentuk koperasi simpan pinjam. Sehingga memungkinkan bagi mereka dalam meminjam uang, dengan bunga yang tidak memberatkan. Juga syarat-syarat peminjaman juga lebih mudah.

Kami juga sarankan bagi pemilik kelong agar menabung ke bank. Tapi ternyata jarak antara tempat tinggal mereka ke bank cukup jauh. Sehingga dengan adanya koperasi, dapat memudahkan para pemilik kelong untuk menabung.

\section{KESIMPULAN}

Kesimpulan dari pengabdian ini adalah beberapa pemilik kelong sudah mulai membuat buku-buku ini agar catatan transaksinya lebih tertata dengan baik. Bagi pemilik kelong yang belum dapat membuat catatan ini, dapat meminta istrinya untuk membantu membuat pencatatan.Pemilik kelong memerlukan bantuan dana untuk memperluas usaha kelong.

Saran dari pengabdian ini adalah perlu dibuat koperasi simpan pinjam agar memudahkan para pemilik kelong berusaha.Selain itu, koperasi juga dapat menjadi tempat penyimpanan uang para pemilik kelong.Pemerintah juga harus mempunyai data mengenai pemilik kelong yang memerlukan bantuan.Hal ini agar pemerintah lebih mendengar apa yang benar-benar dibutuhkan oleh para pemilik kelong. Sehingga bantuan dari pemerintah juga dapat tepat sasaran.

\section{DAFTAR PUSTAKA}

Soemarso, Akuntansi Suatu Pengantar, Edisi 5, Penerbit Salemba Empat, 2002. 
Team Dosen Manajemen, Pengantar Manajemen, Cetakan 1, UMRAH Press, 2016. 